\title{
Юрген Штольценберг
}

\section{ФІХТЕВЕ ПОЛОЖЕННЯ «Я Є». АРГУМЕНТАТИВНО-АНАЛІТИЧНІ МІРКУВАННЯ СТОСОВНО § 1 «ЗАСАДИ ВСЬОГО ВЧЕННЯ ПРО НАУКУ» (1794/95) ${ }^{1}$}

Фіхтеве «Учення про науку» 1794/95 р. являє собою класичний текст філософії, раціональний вміст якого досі не з'ясовано. Щоправда, за останні десятиліття докладено надзвичайних зусиль, щоби посприяти новому визнанню та значенню Фіхтевої філософії ${ }^{2}$. Проте ці зусилля стикнулися 3 критикою, сформованою в контексті нових досліджень з теорії суб'єктивності та самосвідомості, яка засудила внесок Фіхтевої філософії до теорії самосвідомості як «цілковито помилковий» [Pothast, 1971: S. 48], а ті спроби реабілітації його філософії слід наперед вважати марними спробами відживлення вже нездатної до життя теорії. А тому й тезу про нез'ясованість раціонального вмісту Фіхтевої філософії через двісті років після її появи також треба вважати наївною та, за ближчого розгляду, хибною.

Отож останнім часом як з огляду на сучасні тенденції філософії духу, що відмовляється від самосвідомості як специфічної філософської проблеми та доручає їі тлумачення нейронаукам, психоаналізові та психології, так і з огляду на мовно-аналітичний аспект висловленої критики ідеалістичних теорій самосвідомості [див. Tugendhat, 1979] наголошують на тому, що в обидвох випадках самосвідомість розуміють суто як емпіричний феномен або емпірично-психологічний факт [див.

(C) I. Іващенко, переклад, 2014

Переклад з німецької Івана Іващенка за виданням: Jürgen Stolzenberg. Fichtes Satz „Ich bin“. Argumentanalytische Überlegungen zu Paragraph 1 der "Grundlage der gesamten Wissenschaftslehre von 1794/95". In: Fichte-Studien, 1994, 6, S. 1-34. - Прим. ped. Sententiae.

${ }^{1}$ Даний текст $є$ розширеною та переробленою версією рукопису доповіді. Рання версія даного тексту вийшла друком в іспанському перекладі [Stolzenberg, 1990]. За дискусію та критику попередньої версії я дякую Вольфгангові Карлу та Крістіанові Клотцу. Я особливо вдячний Дитерові Генриху за численні запрошення виступити з доповіддю в рамках дослідницьких семінарів з Фіхтевого вчення про науку в Мюнхенському університеті, а також за дискусії ним та учасниками семінарів. Йоргові-Петерові Мітману я дякую за можливість ознайомитися з рукописом його дисертації [див. Mittmann, 1993].

2 Дослідження з Фіхте до 1967 р. узагальнені в [Baumgartner \& Jacobs, 1968]. Огляд літератури з 1962 до 1982 міститься е звіті Г. Гірндта [Girndt, 1984]. Продовження бібліографії Г. М. Баумгартнера та В. Г. Якобса вийшло друком в 3-ому томі серії "Supplementa" Fichte Studien [J. G. Fichte-Bibliographie..., 1993]. 
Horstmann, 1987: S. 224f]. Якщо це розуміння зіставити з критикованими класичними теоріями самосвідомості від Канта до Гегеля, тоді легко побачити, що воно вже не враховує одного з центральних розрізнень цих теорій. У випадку Канта йдеться про розрізнення того, що він називає трансцендентальною та емпіричною самосвідомістю, а також чистою та емпіричною апперцепцією. У випадку Фіхте йдеться про різницю між поняттями абсолютного або чистого Я та Я як розуму (Intelligenz), a тому ясно, що чільний філософський інтерес Фіхте стосувався непсихологічного поняття абсолютного Я.

Якщо мати це на увазі, то можна сказати, що як сучасні тенденції тематизації самосвідомості, так і критика ідеалістичних теорій з боку мовно-аналітичної філософії якраз цілком і повністю загубили те, що треба вважати сутністю цих теорій i, зокрема, теорії Фіхте. Але якщо сучасне становище таке, тоді, мабуть, слід визнати, що й через двісті років раціональний вміст філософії Фіхте не з'ясували, позаяк висунуті проти неї аргументи не мають стосунку до сутності Фіхтевої філософії.

3 огляду на цю ситуацію ми маємо достатньо підстав, щоби по-новому звернутися до текстів, в яких Фіхте розвинув основний принцип свого філософування, 3 метою точнішого та неупередженого їхнього розуміння. Надалі це має відбуватися в формі аргументативно-аналітично орієнтованого дослідження $\S 1$ «Учення про науку» 1794/95 p. ${ }^{3}$ Це дослідження влаштоване також таким чином, що воно звертає увагу на елементи, які вказують на теоретичне тло, знання якого може допомогти зрозуміти особливу організацію цього тексту.

3 цієї метою подальші міркування починаються з тези. Вона стосується способу, в який Фіхте запроваджує в $§ 1$ «Учення про науку» 1794/95 р. положення «Я є». По суті ії можна розуміти як Фіхтеву реакцію на твір Райнгольда «Про відмінність між здоровим глуздом і філософувальним розумом з огляду на фундаменти можливого через них обох знання», який Райнгольд опублікував незадовго до свого від'їзду 3 Єни (отже, безпосередньо перед Фіхтевою появою в Єні) в другому томі «Щодо виправлення попередніх непорозумінь філософів» ${ }^{4}$. У цьому творі, переглядаючи свою програму елементарної філософії, Райнгольд підніс до методичного принципу

3 Даний текст задумано як підготовку до аргументативно-аналітичного коментаря $§ 1$ «Учення про науку» Фіхте 1794/95 p. На підставі обмеженого обсягу він не може зважати на весь текст $\S 1$, а також прояснювати альтернативні інтерпретації. На цій же підставі неможливо розглянути в необхідному обсязі дослідницьку літературу. Фіхтеві твори цитуються надалі згідно з виданням Баварської академії наук (GA), а також за виданням Імануеля Германа Фіхте (SW).

${ }^{4}$ [Reinhold, 1794]. У «Передмові» Райнгольд пояснює, що цей твір було «написано щонайменше за півтора роки до появи повчальної рецензії Енезідемуса (в Загальній літературній газеті)». Очевидно, що мається на увазі Фіхтева «Рецензія Енезідемуса». Спочатку ця рецензія вийшла друком в Загальній літературній газеті Сни за 1794 р., № 47-49 (див. GA I/2, S. 41-67; SW I, S. 3-25). Інше пояснення Райнгольда, що цей твір «був надрукований задовго до того, як до мене дійшла ця сама історія» (Передмова, V), є суперечливим. На підставі висловлювань Райнгольда в ще не опублікованих листах це пояснення можна розуміти так, що цей твір не лише було завершено до появи Фіхтевої рецензії Енезідемуса, а його вже було зверстано. На це мою увагу звернув Марсело Штам, якому я цим завдячую. - Фіхтеве знання цього твору підтверджують такі листи: 1. Фіхте до К. Л. Райнгольда від 1 березня 1794. In: GA III/2, S. 78. (Див. також проект цього листа: ibid., S. 75); 2. Фіхте до М.Й. Фіхте від 26 травня 1794. In: GA III/2, S. 118. 3 огляду на стан джерел не можна навести надійнішого філологічного доказу Фіхтевого засвоєння позиції Райнгольда. Це враховано в нашій попередній тезі, яка наголошує, що Фіхте по суті зреагував на цей твір. 
філософії починання з обов'язкових для спільного глузду переконань ${ }^{5}$ « «У пошуках остаточних засад», пише Райнгольд, «філософський розум спочатку має відштовхуватися від переконань спільного глузду», бо таким чином він радше за все «захищений проти всіх штучних помилок, на які філософувальний розум наражений під час розшуку тих засад» [Reinhold, 1794: S. 17], що, згідно з Райнгольдом, має місце «в емпіризмі, раціоналізмі, скептицизмі та різних модифікаціях цих трьох видів уявлень» [Ibid., S. 16]. Переконання спільного глузду, від яких має відштовхуватися філософувальний розум, Райнгольд позначає як «факти досвіду» ${ }^{6}$.

Як «факт емпіричної свідомості» (SW I, S. 92), а також як положення «з яким погодиться кожен без заперечень», а отже, як положення, істину якого слід вважати переконанням спільного глузду, Фіхте в $§ 1$ «Учення про науку» 1794/95 р. розуміє положення «А $є$ А», з якого починається шлях до найвищої засади, положення «Я є» як виразу «вчинкодії». На цьому шляху виразом «факту» (SW I, S. 94) також ще постає положення «Я є».

Ці свідчення можна вважати очевидними доказами тези про формальне узгодження переглянутої програми методу Райнгольда та розвинутим Фіхте в 1 «Учення про науку» поступуванням до виявлення положення «Я є» ${ }^{7}$.

Завдяки цьому поступуванню Фіхте одночасно зміг виконати багато завдань. На підставі положення, «з яким погодиться кожен без заперечень», він зміг так само звернутися до common sense своєї публіки, яку вперше треба було ознайомити із вченням про науку, як і Райнгольд, який щойно ніби попрощався з Сною тим програмовим поясненням. Приховану полеміку Фіхте з Райнгольдом у цьому пункті можна побачити в тім, що якраз у зв'язку з переглянутою програмою методу Райнгольда він намагався показати, що навіть завдяки їй годі врятувати справу елемента-

5 Теоретичні підстави для Райнгольдового перегляду його першої програми елементарної філософії та наслідків цього перегляду для його подальшого філософського розвитку вперше висвітлили Свен Бернекер і Марсело Штам [Stamm \& Bernecker, 1994]. Див. Також [Henrich, 1991: S. 217f., Bes. 240-244].

${ }^{6}$ Приміром, Райнгольд пояснює: «Спільний та здоровий глузд у своєму пізнанні завжди зважає лише на факти досвіду» [Reinhold, 1794: S. 16].

7 До прихильників позиції спільного глузду в оточенні Фіхте в Єні можна також зарахувати Фридриха Імануеля Нітгамера. Заснований Нітгамером «Філософський журнал товариства німецьких вчених», співробітником якого поряд із Райнгольдом, Маймоном, Шилером також, як відомо, був Фіхте (з 1797 р. він став співвидавцем), мав слугувати, як зазначив Нітгамер у передньому слові до першого тому, опосередкуванню між «спільним вжитком глузду» та сучасною філософією [Niethammer, 1795b]. Із цим Нітгамер водночас пов'язував критику післякантівських спроб обгрунтування філософії з найвищої засади, яку він виклав у першому творі першого тому «Філософського журналу» [Niethammer, 1795b, S. 41f]. Див. також зауваги Дитера Генриха в сьомій примітці згаданого твору [Henrich, 1991: S. 245-246]. Фридрих Август Вайсгун, Фіхтев друг часів його молодості в Шульпфорті, також обстоював права спільного й природного глузду. Так, Вайсгун завершив свою рецензію на Фіхтев «Твір про поняття» як «представник народу, що цілком по праву викладає своє судження з питань філософії», таким «скромним» поясненням: «перспектива тієї позиції, до якої нас підводить пан професор Фіхте, мені не до вподоби на тій підставі, що моїм природним очам показують те, чого воно не схоплюють, і чого природний глузд не осягає» [Weißhuhn, 1794: S. 157].

В оголошенні про свій твір «Тези та антитези стосовно узасаднення нової системи філософії» наприкінці рецензії Вайсгун намагається зблизити спільний та науковий чи філософський глузди. Після передчасної смерті Вайсгуна Нітгамер видав «популярну» та «критичну» частини його «системи філософії». Написати ж догматичну частину автор не встиг. Див. [Weißhuhn, 1795], а також Nacherinnerung des Herausgebers [ibid., S. 116-117]. 
рної філософії, а цим самим він висунув переконання, яке сформував задовго до цього $з$ інших принципових міркувань. Адже, згідно із поясненням самого Райнгольда, «положення свідомості» становить вираз «факту внутрішнього досвіду» ${ }^{8}$ Проте спрямовану проти Райнгольда критику обгрунтування філософії з огляду на «факт свідомості» Фіхте вже висловив в «рецензії Енезідемуса» ${ }^{9}$.

Але початок з положення, істина якого загально визнана, дав Фіхте не лише, сказати б, риторично-стратегічну, а й також систематичну користь. Він дозволив йому піти шляхом, який в контрольованих кроках зміг привести до засадничого принципу його філософії і водночас прояснити його зміст в такий спосіб, який зміг виключити можливе кривотлумачення, що засадничий принцип його філософії можна вважати емпірично-психологічним фактом свідомості.

Спрямоване проти Райнгольда профілювання відмінності між поняттями факту та вчинкодії, яке Фіхте зробив засадою розвинутого в $\S 1$ «Учення про науку» $1794 / 95$ р. ходу аргументу, $\epsilon$ заразом розробкою самокритичного перегляду першого проекту викладу та доказу нового найвищого засадничого принципу філософії, який Фіхте склав у «Власних медитаціях про елементарну філософію» 1793/94 р. Якщо Фіхте спочатку запроваджує там положення «Я», істину якого треба довести не дискурсивним шляхом, а лише з уваги на внутрішнє «споглядання», то у тому ж манускрипті в рамцях методологічних міркувань у пізніше записаній самокритичній рефлексії нашкіцовано альтернативне поступування, згідно з яким положення «Я є» слід «доводити» на підставі положення «А є А». Нову (розроблену в помітній близькості до зміненої програми методу Райнгольда) інтерпретацію цього поступування «доказу» положення «Я є» на підставі положення «А є А» пропонує § 1 «Учення про науку» 1794/95 p.

Отож надалі треба спочатку представити та обговорити першу концепцію найвищого засадничого принципу та нашкіцовані Фіхте альтернативи. Після чого в другій частині статті буде розглянуто шлях, яким Фіхте в $§ 1$ «Учення про науку» 1794/95 р. на підставі положення «А є А» досягнув положення «Я є» як виразу «вчинкодії»

\section{І. Положення Я у «Власних медитаціях про елементарну філософію» 1793/94 p.}

\section{1. Доказ у спогляданні}

«Я є споглядальним» (GA II/3, S. 27), так звучить перша редакція найвищої засади філософії у «Власних медитаціях про елементарну філософію» 1793/94 р. Фіхтев вибір терміна «споглядання» мотивовано наміром подолати Райнгольда. За допомогою нього він намагається оминути коло, яке загрожує виникнути разом зі спочатку зваженим застосуванням терміна «уявлення», бо поняття уявлення слід тлумачити на підставі Райнгольдового «положення свідомості», яке, втім, слід спершу обгрунтувати через положення «Я» ${ }^{10}$.

8 Так, у згаданому творі Райнгольд пояснює, що під поняттям свідомості взагалі «розуміють найзагальніший факт внутрішнього досвіду», виразом якого $є$ «положення свідомості» [Reinhold, 1794: S. 63-64].

${ }^{9}$ У рецензії це сформульовано так: «Перше хибне припущення, яке спонукало його до встановлення засади всієї філософії, полягало, либонь, в тім, що треба відштовхуватися від факту» (SW I, S. 8).

${ }^{10}$ Докладніше про це див. [Stolzenberg, 1986: S. 6f]. 
Інший момент Фіхтевої концепції першої засади полягає в тім, що це споглядання не слід розуміти як інстанцію поняття про те, що треба мислити під свідомістю «Я» ${ }^{11}$. Якщо дотримуватися цієї тези, тоді те, «що є Я», спочатку можна описати лише так, що воно є тим, що осягає самого себе як суб'єкта свідомості у вільному акті рефлексії безпосереднім і дескриптивно невизначуваним чином. 3 вибором терміна «споглядання» пов'язана ще інша теза. За Фіхте, споглядання є водночас інстанцією доказу об’єктивної реальності свідомості «Я». Положення «Я», коментує Фіхте, можна «довести лише через споглядання. Хто справді через це споглядання усвідомлює своє Я, той підтверджує істину цього положення, навіть якщо він його ${ }^{12}$ не зміг би пояснити» (GA II/3, S. 27-28).

Цей спосіб викладу першого положення «Я» як найвищої засади нової елементарної філософії Фіхте видається проблематичним в багатьох аспектах. Так, здається, що 3 тезою про доказ через споглядання лише починається нове коло. Тобто якщо в понятті споглядання мислять стосунок суб'єкта свідомості до чогось безпосередньо даного у внутрішньому чи зовнішньому досвіді і якщо зміст положення, що Я є споглядальним, треба розуміти як вираз рефлексії, в якій суб'єкт свідомості схоплює себе у внутрішньому спогляданні безпосередньо і без інших дескрипцій, тоді суб'єкт свідомості має цьому спогляданню вже передувати, а також вже бути знайомим із самим собою. Бо інакше він не може мати свідомості того, що він сам $є$ тим, до кого в модусі споглядання він має стосунок. Але якщо те, дійсність чого треба довести через цей акт рефлексії, завжди припускають вже як дійсне, тоді не можна казати про доказ $\boldsymbol{Я}^{13}$.

3 цього випливає інший сумнів. Якщо поняття споглядання тут треба розуміти як стосунок до чогось безпосередньо даного у внутрішньому досвіді, тоді положення «Я» стосується те саме, що й Райнгольдового «положення свідомості», тобто воно увиразнює рефлексію щодо початково даного в свідомості факту свідомості. Це означало б, що пізніше, спрямоване проти Райнгольда пояснення Фіхте, що філософія має спиратися не на факт свідомості, а на «вчинкодію» (SW I, S. 8), через яку тлумачать поняття Я, тут ще не малося б на увазі. Місце факту свідомості, який увиразнює Райнгольдове «положення свідомості», заступив би увиразнений в положенні «Я» факт безпосередньої самосвідомості, не вважати який фактом свідомості було б досить проблематично. I цього факту також мав би стосуватися пізніший закид Фіхте проти функції «положення свідомості» як найвищої засади філософії, що воно грунтується на «емпіричному самоспостереженні» (ibid.), а тому не задовольняє критерію необхідності та строгої загальності положень філософії, який вимагає від неї орієнтування на остаточне обгрунтування.

Але ще у «Власних медитаціях» Фіхте дійшов до викладу, який можна розуміти як реакцію на щойно описаний сумнів. Цей виклад дозволяє припустити (втім, без

11 Фіхтеве пояснення таке: «Що є Я, тобто як його треба мислити, тут ще не розглядається» (GA II/3, S. 27).

12 На березі сторінки зауважено: можливість положення.

13 Очевидно, що таким чином можна було би приписати першій Фіхтевій концепції свідомості «Я» так звану рефлексійну теорію самосвідомості. Див. щодо цього статті Дитера Генриха [Henrich, 1966; 1970], а так само нещодавно складений Манфредом Франком огляд теорій самосвідомості з уваги на роботи Дитера Генриха з проблематики самосвідомості [Selbstbewußtseinstheorien..., 1991: S. 435f]. Вартими уваги у зв'язку з історією теорій самосвідомості є Франкові посилання на досі маловідомих в цьому контексті представників англійського емпіризму, приналежних до традиції рефлексійних теорій самосвідомості, таких як Джон Серджент [ibid., S. 440f], ПсевдоМейн [442f], Вільям Шерлок [443f], Роберт Саус [ibid.] і єпископ Пітер Бравн [444f]. 
надійного підтвердження), що підгрунтя виявлених складнощів - радше у невідповідності першого способу викладу, ніж у самій справі. Новий виклад недвозначно увиразнює переконання, що свідомість «Я» не постає в стосунку до чогось відпочатково даного в свідомості, натомість завдячує своїм існуванням спонтанній діяльності, яка ії породжує. Цей спосіб діяльності Фіхте позначив як «виклад» (Darstellung), тоді як епістемічний статус породженої внаслідок цього свідомості «Я» - як «інтелектуальне споглядання». Коректурою чи переглядом першого викладу положення «Я» треба вважати таке пояснення: «Я, що викладає себе самого, інтелектуально споглядається, тобто споглянуте $є$ водночас спогляданням. Тут немає жодного зазнавання (kein Leiden): дія споглядається, і ця дія є спогляданням» (GA II/3, S. 144). У поясненні, що в свідомості Я, яке викладає себе самого, немає «жодного зазнавання», дається взнаки коректура чи перегляд раннього поняття споглядання. Адже це пояснення виразно спростовує стосунок свідомості «Я» до чогось даного, а тому лише «зазнавально» засвоюваного, чого ще не виключало раннє поняття споглядання. А відповідно вже також не може йтися про доказ реальності свідомості «Я» в проблематичному сенсі стосунку до чогось даного у внутрішньому досвіді. Якщо спробувати зберегти ранню тезу про доказ об'єктивної реальності свідомості «Я» через споглядання, тоді про доказ можна було би казати лише в тому сенсі, що його наводять через акт і в акті тієї дії Я, що викладає себе самого ${ }^{14}$. Урешті-решт, як вислід і вираз цієї концепції, ще у «Власних медитаціях» Фіхте сформулював найвищу засаду в спосіб, відомий з «Засади» як «теза $Я$ $\epsilon$ », та експлікував ії так само як і в «Засаді»: «тобто я $\epsilon$, тому щчо (weil) я $\epsilon$, i щуо (was) я є. Я є винятково через буття» (GA II/3, S. 27). Коментарем до безпосередності та непояснюваності свідомості «Я є» треба вважати таке пояснення: «Але яким чином хочеш ти це довести тому, хто заперечує цю чисту свідомість [йдеться про свідомість «Я є»-Ю.Ш.]? Тобто довести ні нам, ні комусь іншому, через щось інше. Хто не має цієї свідомості, той непридатний до філософії» ${ }^{15}$.

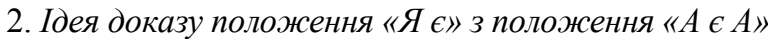

Здається, це не було останнім словом Фіхте. Міркування, яке Фіхте очевидно записав пізніше на березі другої сторінки рукопису «Власних медитацій», на якій він намагався упрозорити поступування власної елементарної філософії, дозволяє припустити наявність зміненої стосовно попередніх міркувань концепції. Тут вперше можна подибати шкіц аргументативного поступування, завдяки якому має бути «доведена» найвища засада. Фіхте пише:

«Здається, що в лекціях ${ }^{16}$ положення я $\epsilon$ справді хибно дедуковано. Утім, я вважаю, що його треба довести. Але позаяк формально воно $є \mathrm{a}=\mathrm{a}$, то його усвідомлюють у колі. На підставі цього можна виснувати, що воно є матеріальним, тому його не усвідомлюють. I навпаки: з припущеного змісту цього положення можна тепер

${ }^{14}$ У цьому сенсі в «Рецензії Енезідемуса» зазначено: «Абсолютний суб'єкт, Я не дається через емпіричне споглядання, а покладається через інтелектуальне» (SW I, S. 10).

${ }^{15}$ GA II/3, S. 144. Цьому відповідає Фіхтеве зауваження в контексті першого викладу положення «Я», що «свідомість "Я" взагалі [годі] пояснити комусь, хто ії вже до того не знає [...] Хто не може усвідомлювати своє Я, той, безперечно, й не претендуватиме на філософування» (GA II/3, S. 27).

${ }^{16}$ Ця заувага дозволяє казати, що Фіхте мав розвинути цю концепцію на момент свого першого виступу перед публікою із щойно розробленим у «Власних медитаціях» проектом системи в домі Лаватера в Цюріху, де приблизно з середини лютого до кінця квітня 1794 р. він читав так звані цюріхські лекції. 
виснувати його формальну правильність. Отже, цього бракує лише в лекції, яку треба обміркувати далі. Для цього потрібен, либонь, глибший розгляд форми та матерії. Можна сказати, що форма, яку Я надає не-Я, є матерією Я» (GA II/3, S. 23).

Новизну цих міркувань слід вбачати в тім, що Фіхте говорить про дедукцію чи доказ, точніше кажучи, про «доказ у колі», а перший крок цього так званого доказу він, вочевидь, бачить у висновуванні з «формального» положення «А=A» «матеріального» положення «Я є». Перше і природне питання, яке можна поставити цьому міркуванню, має стосуватися значення та можливості застосування понять дедукції та доказу, про які тут йдеться.

Спочатку можна припустити, що раніше виключена Фіхте можливість доказу положення «Я є» «через щось інше» стосується встановленого як засновок і визначеного згідно з його змістом положення, адже в цьому випадку не положення «Я є», а те інше положення слід було би розглядати як найвищу засаду і воно зумовлювало б положення «Я є». Дане Фіхтеве пояснення, що положення «Я є» слід все-таки довести і це можна зробити через посилання на положення тотожності, можна потім поєднати 3 попереднім твердженням тому, що цей «доказ» грунтується лише на схемі для положень визначеної форми, що має місце у випадку положення тотожності.

А проте, це міркування виявляється проблематичним із методичного боку. Бо у «Власних медитаціях», а саме в безпосередній близькості до цитованого зауваження, міститься теза про те, що елементарна філософія має обгрунтовувати і логіку ${ }^{17}$. Позаяк Фіхте й пізніше дотримувався цієї концепції ${ }^{18}$, то має бути не дуже зрозумілим, чому засаду логіки, що вочевидь має місце в цитованому зауваженні, тепер роблять вихідною точкою аргументації, яка має вести до матеріально визначеної найвищої засади, а водночас прагнуть зберегти тезу, що те положення треба обгрунтувати на підставі цієї засади; бо тоді здається зовсім незрозумілим, як можна уникнути пов'язаного із цим кола.

Втім, слід відразу вказати, що Фіхте цілком усвідомлював це коло. Приміром, у тому самому контексті знаходимо: «Згідно зі своєю формою елементарна філософія підпорядкована загальній логіці, а загальна логіка - елементарній філософії. Тут наявне коло» (GA II/3, S. 22). Через посилання на саме це пояснення можна також спробувати виправдати та прояснити нинішню Фіхтеву тезу про «доказ у колі» в стосунку до найвищої засади.

Утім, така спроба швидко зазнає поразки. Щоправда, висловлювання, що положення «Я є» формально слід осягати як «A=A», можна розуміти так, що воно підпорядковане положенню тотожності як засаді загальної логіки. Але зміст поступу міркування та експлікація циркулярності доказу полягає не в тезі, що на підставі змісту положення «Я є» треба доводити значущість положення тотожності як засади логіки. Цей зміст полягає радше в тезі, що на підставі «припущеного змісту» положення «Я є» можна довести «формальну правильність», тобто значущість тотожності Я, яку слід в цьому положенні мислити. Що це є змістом тези і що вона насправді не містить претензії на обгрунтування значущості положення тотожності як засади

17 «Сама логіка взагалі є чимось в людському духові. Елементарна філософія має обгрунтовувати також їi» (GA II/3, S. 22).

18 Так, у «творі про поняття» в 6 під назвою «Як загальне вчення про науку зокрема стосується логіки?» Фіхте пояснює: «3 цього випливає визначений стосунок логіки до вчення про науку. Логіка не обтрунтовує вчення про науку, натомість вчення про науку обгрунтовує логіку. [...] кожне логічне положення, і всю логіку [слід] доводити на підставі вчення про науку» (SW I, S. 68). 
логіки, можна показати на підставі систематичного плану як «Власних медитацій», так і «Вчення про науку» 1794/95 р. Ії̈ можна коротко описати так: усунення суперечливих описів конститутивних умов свідомості, які випливають зі зваженої в $\S 1$ тотожності Я та наступних положень цього параграфу, становить доказ правильності цієї тотожності Я. Останнім етапом цього процесу є перехід до практичної філософії, в якій суперечності в понятті Я, як абсолютної, так і щодо сфери не-Я, треба уникнути через запровадження поняття прагнення (див. SW I, S. 246f). На цей систематичний контекст вказує також останнє зауваження Фіхте, що форма, яку Я надає не-Я, $\epsilon$ матерією Я. Адже форма, яку Я має надати не-Я через концепцію прагнення, $є$ формою узгодження із Я, в якій не-Я слід покладати як реальність. Але буття сукупністю всієї реальності можна схарактеризувати як матерію Я (див. SW I, S. 109).

3 цього для розуміння цитованого зауваження випливає, що проблематичною $\epsilon$ радше його друга, а не перша частина. Адже порушене на початку питання лишилося без відповіді, тобто питання, в якому сенсі в цій частині взагалі може йтися про висновування з положення «А=A» положення «Я є», себто як можна прояснити логіку такого висновування, яке в цитованому зауваженні очевидно не розвивається як таке.

Перед тим, як спробувати це прояснити, має сенс ще раз докладніше розглянути Фіхтеве висловлювання, яке має утворювати основу цього висновування. Тоді треба констатувати, що це висловлювання є висловлюванням зовсім не про положення «A=A», а про положення «Я є». Саме це положення є суб' єктом цього висловлювання. Про нього Фіхте говорить дві речі: по-перше, що воно задовольняє формі тотожності, по-друге, лише в цій формі, точніше кажучи, лише як ця форма воно є предметом свідомості. Якщо спочатку абстрагуватися від інтерпретаційних проблем, що виникають разом із другою частиною висловлювання, тоді можна констатувати, що в цьому зауваженні Фіхте не тематизує логічне положення «А=A» як таке і на його підставі твердить про можливість висновування положення «Я є». Радше в першому крокові міркування положення «A=A» вже устосоване до положення «Я є», позаяк положення «A=A» інтерпретують як його логічну форму. Але це значить, що значущість положення «Я є», а цим самим також його зміст, який лише треба виснувати, вже припускають. Це дозволяє зробити висновок, що тут зовсім не може йтися про висновування в тім сенсі, що воно передбачає аргументацію від засновку, який ще не належить до царини вчення про науку, до його засадничого принципу, позаяк те, що тут слід виснувати, вже на початку береться до уваги. Позаяк не це $\epsilon$ колом, про яке йдеться в цитованому зауваженні, то Фіхтева теза про доказ положення «Я є» може стосуватися лише другої частини зауваження. Тоді тезу про висновування в першій частині можна розуміти лише як помилкове характеризування Фіхтевої експлікації зв'язку форми та матерії в стосунку до найвищої засади. Тоді в цій експлікації, яку ще треба зробити, та на підставі здобутої з неї інтерпретації засадничої функції положення «Я є» треба вбачати поступ або коригування стосовно міркувань «цюрихських лекцій».

Але можливий ще й інший перспективний висновок у стосунку до подальшого розвитку. Він водночас придатний для розв'язку складнощів розуміння тези про висновування з положення «A=A» положення «Я є». Якщо зважають на Фіхтеву тезу, що зміст положення «Я $є »$, на відміну від положення «А=A», «не усвідомлюють», тоді природною $є$ думка, що стверджену тут можливість висновування з положення «А=A» положення «Я є» можна доводити в поступуванні, яке починається 3 методичних nідстав, відтак - 3 положення « $\mathrm{A}=\mathrm{A} »$ (бо лише його «усвідомлюють»), а не 3 положення «Я є» та увиразненого в ньому змісту. Це роблять, щоби потім показати, що $з$ 
положення «A=A» треба висновувати положення «Я є». Авжеж, заразом треба прояснити та обгрунтувати, що (i чому) зміст положення «Я $\epsilon$ не $\epsilon$ чимось, що усвідомлюють як зміст положення «А $є$ А».

Це поступування Фіхте розпочав у $\S 1$ «Учення про науку» 1794/95 p ${ }^{19}$. Отож слід його розглянути.

\section{II. Шлях до положення «Я є» в 11 «Засади всього вчення про науку» 1794/95 p.}

\section{1. Положення «А $\epsilon$ А»}

У $§ 1$ «Учення про науку» 1794/95 р. Фіхте схарактеризував положення «А є А» як положення, яке має не лише загальне значення як істинне положення. Він схарактеризував його також як положення, що взагалі не потребує доказу, а тому вважається положенням, яке $\epsilon$ «безумовно, тобто без якоїсь іншої підстави, певним» (SW I, S. 93). Фіхте не дає у викладі своєї відправної точки можливого обгрунтування того, що положення тотожності вважається безумовно певним, оскільки воно є логічно істинним і кожне поняття та кожне висловлювання його формально передбачають. Непрямо цей виклад також містить підставу для того, що такого розважання тут і не треба наводити. Адже Фіхте розуміє це положення як приклад «факту емпіричної свідомості» (SW I, S. 92). Із цим водночас пов'язана інтерпретація позиції спільного глузду. Якщо факт є тим, що увиразнює істинне положення, і якщо факт емпіричної свідомості є фактом, який має статус даного через досвід, тоді можна сказати, що це положення характеризують як положення, яке спільний глузд стверджує як безумовне та певне без якоїсь іншої підстави, бо він, з одного боку, безпосередньо усвідомлює увиразнену в ньому думку, якщо вона є думкою, як факт внутрішнього досвіду. 3 іншого боку, оскільки спільний глузд завжди виявляє це положення у вжитку та у цьому сенсі вважає його безумовно істинним також і в «зовнішньому досвіді». Але для Райнгольда, як і для Фіхте, кваліфікування істинності того, що дане свідомості безпосередньо у внутрішньому чи зовнішньому досвіді, становить рису спільного глузду ${ }^{20}$.

19 У своєму «творі про поняття» Фіхте вперше виконав спрямовану до самого себе в цитованому міркуванні вимогу «глибшого розгляду форми та матерії». Це вимагає окремого дослідження. Але тут ми маємо від нього відмовитися. Треба згадати лише те, що у «творі про поняття» Фіхте (в контексті розгляду зв'язку вчення про науку та логіки) спирається на положення «А є А» і планує його аналіз так, що він веде до положення «Я є». Проте цей перехід не відбувається так, що положення «Я є» обгрунтовано запроваджують до ходу аналізу, як це відбувається в ході $\S 1$ «Учення про науку» 1794/95 р. Натомість його запровадження відбувається на підставі суто тетично сформульованого припущення: «Покладене в попередньому положенні А означає Я» (SW I, S. 69).

20 У своєму коментарі до $\S 1$ «Учення про науку» 1794/95 р. Петер Бауманс розуміє Фіхтеву інтерпретацію положення «А є А» як положення, про яке спільний глузд стверджує, що воно «безумовно, і без якоїсь іншої підстави певне», таким чином, що «сам спільний глузд [...] приписує собі знання а priori» та стверджує щось, «що не потребує жодного обгрунтування такого типу, який знайомий лише їй, емпіричній свідомості», так що за Баумансом можна сказати: «Емпірична свідомість, точніше кажучи, емпірична самосвідомість охоплює свідомість неемпіричних станів справ» [Baumanns, 1974: S. 162]. Неясно, чи вважає Бауманс, що спільний глузд, якщо він приписує собі знання а priori, також усвідомлює те, що він це робить, чи він de facto ними орудує, не усвідомлюючи їх. У перспективі Фіхтевої аргументації не може бути жодного сумніву, що спільний глузд не може приписувати собі на підставі самого себе знання а priori, тому що він зупиняється винятково в царині того знання, яке відоме йому з досвіду. Це також прояснює намір Фіхте, прояснити спільному глуздові те, що стверджувана ним безумовна певність положення «А є А» підпорядкована умові, яка не є жодним фактом емпіричної свідомості. 
Поступ аналізу в другому уривку ${ }^{21}$ можна розуміти на підставі початкового наміру унаочнити спільному глуздові формальні характеристики стверджуваної безпосередньої певності в стосунку до положення «А $\epsilon$ А» ${ }^{22}$. Перший крок полягає в тім, що абстрагуються від увиразненого в положенні «А є А» змісту тотожності А із собою та тематизують безумовно стверджувану щодо цього положення певність ${ }^{23}$. Це відбувається тому, що положення «А є А» тлумачать як категоричне судження та надають йому форми гіпотетичного судження. У твердженні, що положення «А $є$ А» певне в собі (an sich gewiß), не покладають, за Фіхте, що є дещо, чому відповідає предикат А, а лише необхідний зв'язок: «якщзо є А, тодi є А». Отже, в своїй точнішій формі цей зв'язок звучить так: «Якщо є дещо А, тоді $є$ дещо А». Вочевидь, Фіхтеве переформулювання ${ }^{24}$ має увиразнити, що в теперішньому контексті йдеться не про визначений зміст, який треба вкладати в А, і не про існування чогось у цьому визначеному змісті, якого стосується твердження про певність положення «А $є$ А», натомість лише про форму цього положення, тобто про стверджувану щодо нього безумовну певність. Ця форма викладена в «безумовно», тобто «без якоїсь підстави» (SW I, S. 93) покладеному необхідному зв'язку обидвох частин кондиціоналіса. Потім цей зв’язок «попередньо» позначається як «Х» [ibid.].

\section{2. Х та Я як факти свідомості}

Пояснення, з якого починається наступний 3-ий уривок, «з огляду на саме А, чи є воно, чи ні, внаслідок цього ще нічого не покладено» [ibid.], знову повертається до сформульованого в другому уривкові пояснення, що в твердженні про безумовну певність положення «А $є$ А», не говориться, що А $є$. Це треба розуміти лише так, що не говориться про існування чогось, чому відповідає визначений предикат ${ }^{25}$. Питання, яке висновують 3 цього пояснення і відповідь на яке визначає поступ аналізу, звучить: «Тож за якої умови $\epsilon$ A?» (SW I, S. 93).

Сенс цього питання не можна розуміти так, що у зв'язку із розглянутим у другому уривку прикладом замкненого між двох прямих ліній простору тепер питають про специфічні умови внутрішньої визначеності предмета, за яких можна зрозуміти, чи існує так визначений предмет та чи міг би він існувати. Надалі Фіхте відкинув цю можливість 3 поясненням, що в стверджуваній безумовній певності щодо положення тотожності немає знання про те, «чи і як А взагалі покладено» (SW I, S. 94). А також

${ }^{21}$ Йдеться про кроки аргументу в $§ 1$ «Засади всього вчення про науку», які Фіхте пронумерував. Усього таких кроків/уривків десять. - Прим. перекладача.

${ }^{22}$ Цим водночас починається перший крок Фіхтевої «абстрагувальної рефлексії», в якій «одне за іншим [відокремлюють] емпіричні визначення, доки не залишиться те, від чого годі абстрагуватися і що не можна відокремити» (SW I, S. 92). Те, що лишається наприкінці, є змістом положення «Я є» як виразом «вчинкодії». Але в такий спосіб, як зазначено на початку $§ 1$ щодо зв'язку рефлексії та абстракції в стосунку до поняття вчинкодії, слід відрізняти те, «що [спільний глузд - Ю.Ш.] може про це спочатку гадати» (SW I, S. 91), від того, як це слід мислити насправді. Ця відмінність стосується інтерпретації Я як «факту» та Я як «вчинкодії».

${ }^{23}$ Приміром, початок другого розділу лунає так: «Через твердження, що попереднє положення певне в собі, покладають [...]» (SW I, S. 93; курсив - Ю.Ш.).

24 Див. щодо цього пояснення Крістіана Вольфа в § 226 латинської логіки: «Propositiones categoricae aequivalent hypotheticis et ad eas reduci possunt» (Категоричні положення еквівалентні гіпотетичним і їх можна до них редукувати) [Wolff, 1983: S. 229].

${ }^{25}$ Очевидно, що це також сенс Фіхтевої експлікації положення існування «А є» у формі «існує якесь А», яку треба тлумачити лише так, що існує дещо, чому відповідає визначений предикат. 
не може йтися про виявлення специфічних епістемічних умов, за яких можлива свідомість визначених, наявних у просторі та часі предметів. Це неможливо, бо умови такого гатунку ще зовсім не можуть даватися взнаки у контексті запровадження найвищої засади.

Якщо звернутися до розгортання третього уривку з метою отримати позитивну відповідь, тоді виявиться, що розвинутий у ньому аналіз надалі стосується позначеного через Х зв'язку умови. Це відбувається так, що тепер зв'язок умови стає темою аналізу в специфічній інтерпретації. Вона полягає у тім, що X пов'язують зі вперше тут запровадженим «Я»: «Х щонайменше», так починається уривок 3 -а ${ }^{26}$, «покладене 6 Я та через Я, адже Я є тим, що судить в попередньому положенні, тобто судить про Х як про закон» (SW I, S. 93). 3 обставини, що темою третього уривку є лише експлікація цього стосунку X до «Я», можна досягнути вирішальної для розуміння цього уривку думки, що із запровадженням поняття Я, як може здатися зі вступного пояснення цього уривку, не наводиться та умова, за якої можна позитивно розв'язати досі відкрите питання, існує А чи ні. Систематичне значення запровадження поняття Я полягає радше в тім, що твердження про проблематичне існування А виразно експлікується за умови, що позначений через $\mathrm{X}$ необхідний зв'язок $є$ станом справ емпіричної свідомості. Це увиразнюють так, що Х «покладене в Я, а також через Я». Що мається під цим на увазі й які наслідки з цього випливають, третій уривок і удокладнює.

Фіхтеве посилання на інстанцію Я не можна розуміти та оцінювати як необгрунтоване передбачення поняття абсолютного Я. Це посилання радше виправдовує концепція, яку треба зараховувати до методичних передумов учення про науку. На ці передумови Фіхте вказує в шостому уривку $\S 1$. Там, у відомий з «твору про поняття» ${ }^{27}$ спосіб, судження характеризується як одна 3 умов діяння людського духу, які «треба припускати як відомі та з'ясовані» (SW I, S. 95) задля можливості рефлексії вчення про науку. Проте в шостому уривку Фіхтевого коментаря міститься зворот, який в цій формі ще не подибується в «творі про поняття». Це пояснення в тім, що «всі умови дії» мають бути дані та передбачені «в емпіричній самосвідомості» (ibid., курсив мій - Ю.Ш.).

Тут також можна припустити, що цим поясненням, як і концепцією починання 3 факту емпіричної свідомості, Фіхте долучається до Райнгольда, а саме до його теорії самосвідомості, вже розвинутої у «Спробі нової теорії людської спроможності уявлення» [Reinhold, 1789] і продовженої у згаданому ${ }^{28}$ творі за змінених методичних засновків починання з переконань спільного глузду ${ }^{29}$. У цьому контексті Райнгольд скрізь вживає поняття фактів самосвідомості, під яким мається на увазі сукупність, як пише Райнгольд [Reinhold, 1794: S. 41], «операцій душі» (Operationen des Gemüts), які у «внутрішньому досвіді» слід уявляти як «факти внутрішнього досвіду» й

26 Третій уривок складається $з$ трьох кроків, які Фіхте позначив літерами. У перекладі зберігаються латинські літери a, b та с. - Прим. перекладача.

27 Йдеться про твір «Про поняття вчення про науку або так званої філософії» (Über den Begriff der Wissenschaftslehre oder der sogenannten Philosophie), який Фіхте видав у 1794 р. перед «Засадою всього вчення про науку». - Прим. перекладача.

28 Мається на увазі згаданий вище твір Райнгольда «Про відмінність між здоровим глуздом і філософувальним розумом 3 огляду на фундаменти можливого через них обох знання». Прим. перекладача.

${ }^{29}$ Стосовно Райнгольдової теорії самосвідомості у «Спробі нової теорії людської спроможності уявлення» див. прим. 17 мого дослідження, с. 43, прим. 58. Див. також [Henrich, 1989: 139f] i прим. 7 до [Stamm \& Bernecker, 1994]. 
остаточні основи яких має розшукувати філософувальний розум [ibid., S. 47, 59-65] 3 цього контексту зрозуміло, що Райнгольд зараховує до фактів внутрішнього досвіду також самосвідомість ${ }^{30}$.

Якщо припущення, що Фіхте й у цьому місці орієнтується на теоретичну програму Райнгольда, слушне, тоді Фіхтев концепт підведення до положення «Я є» містить інший критичний висновок проти елементарної філософії Райнгольда. Фіхте послуговується Райнгольдовою теорією самосвідомості, щоби водночас ії подолати, а саме так, що він розташовує ії в рамцях простого підведення до принципу вчення про науку та за допомогою поняття абсолютного Я підпорядковує іi, врешті-решт, поняттю самосвідомості, яке лише й позначає так звану остаточну основу «всіх фактів емпіричної самосвідомості» (SW I, S. 95), що свідчить про імпліцитне критичне посилання на Райнгольда.

Отож посилання на інстанцію Я в сенсі емпіричної самосвідомості та на дію судження, яка $є$ одним $з$ предметів Я, безпосередньо дозволяє висновування про присутність X в Я, з якої починається хід аргументації третього уривку, адже $\mathrm{X}$ позначає лише форму того судження. Позаяк певність «А $є$ А» безумовно і без якоїсь підстави покладається через Я емпіричної самосвідомості, тому воно також може розуміти лише самого себе як основу цього свого твердження та позначеного через X взаємозв'язку. Тому можна сказати, що «Х щонайменше покладене в Я та через Я» та «має бути даним Я через саме Я» ${ }^{31}$.

Тоді тезу уривку 3-b, що також «А покладене в Я та через Я» (ibid.), можна легко зрозуміти як аналітичний вислід функції $\mathrm{X}$ та обставини, що $\mathrm{X}$ вважають змістом емпіричної самосвідомості. Позаяк позначений тут через X взаємозв'язок $є$ посутньо взаємозв'язком $y$ стосунку до $A$, а цей стосунок $є$ змістом емпіричної свідомості, тоді й А також має бути змістом емпіричної самосвідомості та бути як $\mathrm{X}$ «покладеним в Я та через Я».

Згідно зі своєю логічною структурою уривок 3-с і собі постає викладом аналітичної імплікації описаного в 3-b стану справ, що на підставі покладеного через X взаємозв’язку А присутне як зміст емпіричної самосвідомості або Я. Спосіб, в який описане таким чином А присутнє як зміст емпіричної самосвідомості, увиразнює останнє речення уривку 3-с. Воно звучить так:

«Отже, попереднє положення [положення «якщо є А, тоді є А» - Ю.Ш.] можна увиразнити і так: якщо А покладене в Я, тоді воно покладене; або - тоді воно $\epsilon$ » (SW I, S. 94).

30 «До фактів внутрішнього досвіду як такого також належить самосвідомість як факт, без якого не були б мислимі всі інші факти» [Reinhold, 1794: S. 59].

${ }^{31}$ SW I, S. 94. Теза Петера Бауманса стосовно третього уривку, що «для виявлення вчинкодії [...] Я увиразнюють у подвійній перспективі»: «як Я, що судить згідно з “А є А”, та як Я, що дається самому собі» [Baumanns, 1974: S. 166], не є слушною в двох аспектах, про що свідчить зіставлення $з$ текстом. 3 одного боку, Я судить не згідно 3 «А $€ \mathrm{~A} »$, а «згідно 3 Х як законом». 3 іншого, внаслідок цього воно дається не собі самому, натомість дає собі самому лише закон, який позначає Х. У своїх міркуваннях, що Фіхте за допомогою поняття «абсолютної певності як такої натякає на Я-походження знаного $з$ абсолютною певністю стану справ», Бауманс, здається, не помічає, що це не стан справ, який за Фіхте дається Я через саме Я, натомість акт судження та імпліковане в ньому Х. Помилковою також виявляється теза Бауманса, що вже тут Фіхте йдеться про висновування «з суто емпіричної певності [...] трансцендентальносуб'єктивного походження певності» [ibid.]. Тут, видається, Бауманс проочує значення X, a так само факт, що таку спробу Фіхте робить лише в шостому уривку. 
Ясно, що зміст цього речення стосовно статусу А не виходить за межі сказаного в другому уривку, а це значить, що твердження про існування А і надалі залишається проблематичним. Бо стверджуване в останній частині речення існування А очевидно підлягає тій проблематичній умові, щ̧о існування А покладено як зміст емпіричної свідомості.

А втім, не дуже ясно, у чому точно полягає зміст цього речення. Спочатку його можна зрозуміти так, що в цьому положенні остаточно увиразнено стан справ, що твердження про безумовну певність положення «А є А», форма якого увиразнена через необхідний взаємозв'язок членів кондиціоналіса, є дією Я, а тепер це викладається так, що обидві позиції А та їхнього взаємозв'язку «покладені в Я та через Я».

Але цим самим не сказано вирішального. Позаяк останнє речення уривку 3-с сформульоване не так: «якщо А покладене в Я, тоді А покладене в Я», а так: «Якщо А покладене в Я, тоді воно покладене; або - тоді воно $є »$. Обгрунтування того, що присутня в першому члені кондиціоналіса умова в стосунку до А, тобто бути покладеним в Я, не міститься в другому члені, розвинута в уривку 3-b. У цьому уривку члени кондиціоналіса схарактеризовані як члени необхідного взаємозв'язку між «невідомим покладанням А та абсолютним покладанням того самого А за умови того невідомого покладання» (ibid.). I очевидно, що це «абсолютне покладання», яке слід увиразнити в другому члені кондиціоналіса через те, що скасовано умову, що А покладене в Я, а також, що абсолютну покладеність (Gesetztsein) треба мислити як «буття» та як існування. Але що тут мається на увазі?

Відповідь на це питання виявляється тоді, коли зважають, що це речення становить результат аналізу умов безумовно покладеного X та його стосунку до «Я», а $\mathrm{X}$ Фіхте схарактеризував як «закон». Тоді можна сказати, що на підставі своїх логічних властивостей необхідності та загальності закон має свою основу лише у мисленні і в Я, бо він стосується стану справ, який також існує незалежно від того, чи його мислять в Я. У даному випадку це означає, що твердження про існування А можна мислити як необхідне тоді, коли А покладене через Я як таке, що існує. Але позаяк разом $3 \mathrm{X}$ також мислять якість безумовності цієї необхідності, то це означає, що немає жодної підстави, на якій можна було б осягнути необхідність твердження про існування Я. 3 цього випливає, що це твердження безумовне, а отже, цим самим стверджується стан справ, який не має статусу суто суб'єктивно значущого уявлення, а також існує незалежно від того, присутній він як зміст свідомості, чи ні. Тому можна сказати: коли А покладене в Я через X як таке, що існує, то воно існує в собі та незалежно від того, чи покладене воно в Я, чи ні. Либонь, як неодноразово наголошує Фіхте, не з'ясовано, чи виконано умову, щзо А покладене як таке, що існує, а без специфічної інтерпретації А цього й не можна з'ясувати.

Фіхтева теза в тім, що це обмеження в стосунку до змісту свідомості «Я» скасовано і це можна побачити з іншої рефлексії про зв'язок Х та Я, яке судить про Х. Ці тези та їхнє обгрунтування є темою наступних уривків $\S 1$.

\section{3. Перехід від Х до положення «Я $є$ Я»}

Четвертий уривок починається так:

«Отже, Я опосередковано через X покладає: А $є$ для Я, яке судить, безумовно і винятково в силу його покладеності в Я взагалі» (SW I, S. 94).

Зміст цього пояснення можна перефразувати таким чином, що Я лише тоді може усвідомлювати буття А, коли воно усвідомлює, що Х є основою буття А. Очевидно, 
що цим самим не відбувається поступ стосовно досягнутого в уривку 3-с стану. Цей поступ дається взнаки лише через додатковий висновок, що внаслідок цього покладено, «що в Я [...] є дещо, що завжди тотожне собі, завжди $є$ одним й тим самим» (SW I, S. 94). Зміст цього висловлювання спочатку можна зрозуміти так, що Фіхтева теза про щось, «що завжди тотожне собі, завжди $є$ одним й тим самим», стосується лише логічної форми тотожності А із собою, з якої починався аналіз і яку, за умови розвинутої тепер інтерпретації теорії свідомості, слід так само мислити як стан справ, який можна зобразити фактом емпіричної свідомості, а тому - фактом «в Я».

Утім, такий спосіб прочитання не зважає, що це висловлювання формулюється як висновок з дотепер досягнутого результату аналізу, який є аналізом стосунку $X$ до Я. Це веде до того, що Фіхтеву тезу про щось, що завжди тотожне собі, завжди є одним і тим самим, треба розуміти так: під нею мається на увазі лише формальний характер позначеного через X взаємозв'язку. Далебі, можна сказати, що цей взаємозв'язок тому тотожний собі, що він містить необхідний взаємозв'язок обидвох членів кондиціоналіса, який і собі становить форму безумовної певності чогось. Отож в усіх випадках, в яких твердять про безумовну певність в стосунку до чогось, цей взаємозв'язок $є$ інваріантно тим самим, а тому можна сказати, що в Я, яке судить про Х як про закон, «є щось, що завжди тотожне собі, завжди є одним і тим самим».

Це $X$, так звучить останній та вирішальний крок цього уривку, «можна увиразнити також так: Я=Я; Я є Я» (ibid.).

Якщо питають, яким чином треба розуміти стверджуваний в цьому крокові стосунок між схарактеризованим через X взаємозв'язком і свідомістю тотожності Я, як вираз якої треба, вочевидь, тлумачити положення «Я є Я», тоді можна відштовхуватися від засновку, що Фіхте описав схарактеризований через X необхідний взаємозв'язок в уривку 3-с як об'єднання обидвох позицій А. Тоді цей стосунок можна розуміти так, що свідомість, яку суб'єкт судження має про це об'єднання, передбачає свідомість тотожності себе самого. Якщо виходити з того, що через X витворено необхідний, виражений через кондиціоналіс взаємозв'язок між обома способами покладання А, тоді спосіб, в який з боку суб'єкта, що судить, має бути можливою свідомість про покладене через X буття А, не можна розуміти так, що суб'єкт орудує свідомістю лише одного чи даного покладання А. Це неможливо тому, що буття А істотно опосередковане через $\mathrm{X}$, але $\mathrm{X}$ передбачає необхідний взаємозв'язок обох способів покладання. Отже, якщо розуміти свідомість суб'єкта, що судить, в стосунку до А лише так, що він стосується в той самий свідомий спосіб до свого даного покладання А, тоді він не міг би - як мав би - орудувати свідомістю взаємозв'язку цих обох способів покладання А. У даному випадку це означало би, що Я не зовсім могло б орудувати свідомістю якогось змісту, адже те, що покладене «в Я» та «для Я, що судить», $є$ покладеним через Я необхідним взаємозв'язком, який обгрунтовує буття А. 3 цього випливає, що, як каже Фіхте, Я, яке судить, для якого А «через Х [...] є безумовно та винятково в силу своєї покладеності», треба мислити не лише як єдність, а як таке, що усвідомлює свою тотожність в стосунку до пов'язаних через $\mathrm{X}$ способів покладання А та їхнього взаємозв’язку. Свідомість цієї тотожності увиразнює положення: «Я є Я» 32 .

${ }^{32}$ На відмінність між єдністю та тотожністю свідомості «Я» звернув увагу Дитер Генрих у своєму дослідженні про Кантову трансцендентальну дедукцію чистих понять глузду [Henrich, 1976: S. 54f]. Пізніше Фіхтеве пояснення тотожності Я, згідно з яким «Я, яке поклало А, подібне тому, в якому воно покладене» (SW I, S. 99), відсилає до концепції теорії судження, яка нашкіцована у примітці до сьомого уривку (див. SW I, S. 96). У цій примітці акт предикації тлумачиться як акт 
Очевидно, що ця аргументація тісно пов'язана із Кантовою теоремою початковосинтетичної єдності апперцепції. Тоді Фіхтеву заувагу наприкінці § 1 слід було б читати $з$ цієї перспективи, у згоді з якою Кант «[натякав] на наше положення, як абсолютну засаду всього знання [...] в своїй дедукції категорій, [...] але ніколи визначено не встановив його як засаду» (SW I, S. 99). 3 цієї перспективи організація ходу до найвищої засади вчення про науку вмотивована не лише критичним долученням до переглянутої Райнгольдової програми методу та проясненням позиції спільного глузду про приховані для нього імплікації його твердження про певність положення «А $є$ А», а й також орієнтуванням на вершину «спекулятивного» розуму теоретичної філософії Канта ${ }^{33}$. Утім, у даному контексті цю перспективу не можна розглянути ближче ${ }^{34}$.

Якщо ще раз звернутися до Фіхтевого формулювання вирішального кроку - переходу від «безумовно покладеного Х» до положення «Я є Я», тоді має здаватися, ніби щойно зроблена реконструкція насправді все ж не в змозі пояснити цей перехід. Цей крок описано таким чином, що «безумовно покладене Х» можна також увиразнити через положення «Я є Я». Якщо запитати, яким чином зроблена реконструкція у змозі розуміти сенс виразу «увиразнювати», то слід визнати, що вона не приділила йому жодної уваги та у змозі розуміти його винятково як скорочений, довільний спосіб виразу необхідного стосунку умови (Bedingungsverhältnis) між покладеним

рефлексії Я щодо себе. Відправним пунктом цієї концепції $є$ припущення, що покладене на місці суб'єкта А покладається Я як зміст його свідомості. Потім Фіхте тлумачить покладене на місці предиката А як таке, яке «виявляє покладеним в собі Я, що робить себе самого об'єктом рефлексії, тому що Я поклало його спочатку в собі». Тому акт предикації можна тлумачити як результат акту саморефлексії суб'єкта, що судить, в якому Я предикує щось «не властиво про А», «а про самого себе, а саме що воно виявляє в собі A» (SW I, S. 96). А тому також можна сказати, що треба припускати тотожність між Я, яке поклало А в собі, та тим Я, в якому покладене воно. А втім, ця концепція знецінює інтерпретацію, яку Фіхте дав положенню «А $є$ А» в головному тексті. Адже очевидно, що на підставі простої рефлексії про щось дане в свідомості зовсім не можна пояснити модальність необхідності, яка пов'язана із твердженням про безумовну певність положення «А $€$ A» та увиразнена через позначку «Х». Виразом цього дефіциту можна вважати завершальне Фіхтеве зауваження, що «є» - не «Х» - увиразнює перехід Я від покладання до рефлексії про покладене. Тому також реконструкцію аргументу, який закладає підвалини крокові від «Х» до положення «Я є Я», не можна задовільно здійснити щодо цієї концепції теорії судження, натомість їі слід здійснювати з огляду на значення «Х».

33 Петер Бауманс також наблизив наявну в останньому крокові четвертого уривку думку до Кантової синтетичної єдності апперцепції, але виснував з цього критичну тезу, що як в цьому місці, так і в подальшому перебігові § 1 досягається винятково «єдність теоретичної самосвідомості», а «“абсолютний” характер Я так само мало виявляється, як і його характер як вчинкодії» [Baumanns, 1974: S. 171]. Здається, що підвалини Баумансової інтерпретації та критики тут і надалі закладає думка, що під поняттям абсолютного Я Фіхте мав на увазі не аспект комплексного стану справ «свідомість», а стан справ, що існує самостійно для себе. Це розуміння, на яке натякає вираз «абсолютний», суперечить Фіхтевому поясненню в коментарі до § 3 , що жодна з розвинутих у трьох засадах форма покладання не можлива без іншої (див. SW I, S. 115). Це лише думка, якій надано форму засад, якої Фіхте дотримується вже в ході розвитку від «А $є$ А» до «Я $\epsilon »$, тобто думка, яка хоч і безумовно реалізує свідомість «Я є», проте все ж із посиланням на стан справ свідомості, тобто з посиланням на зміст, який усвідомлюють. Останні формальні умови можливості усвідомлення змісту розвивають три засади, а саме так, що вони становлять останні формальні умови кожного визначення чогось як чогось. Останньою умовою для цього $є$ увиразнена в положенні «Я є» свідомість Я про свою тотожність і дійсність. Див. щодо цього SW I, S. $109,115 f, 122-123$.

${ }^{34}$ Див. щодо цього нижче прим. 38. 
через Я та для Я, позначеним через Х взаємозв'язком та обома способами покладання А та свідомості тотожності Я в стосунку до цього взаємозв’язку.

Утім, ця реконструкція не помічає вирішальної суті цього стосунку. Вона випливає 3 методологічних міркувань, які Фіхте розгорнув у своєму «творі про поняття» щодо логічної конституції найвищої засади. Для найвищої засади має мати силу те, що вона, позаяк не може отримати свою значущість із певних положень, «має бути певною безпосередньо та через саму себе» (SW I, S. 49). У стосунку до зв'язку форми і змісту (ibid.), який слід розрізняти в кожному положенні, Фіхте тлумачить характерну для найвищої засади безпосередню певність, яку треба обгрунтовувати лише не підставі найвищої засади, таким чином, що «ії зміст є ії формою, i, навпаки, iii форма визначає іiї зміст». Або форма найвищої засади не лише дана через неї, «а й встановлена як безумовно значуща для їі змісту» (ibid.)!

Систематичне значення, яке відповідає позначеному через X взаємозв’язку, можна описати на підставі цих пояснень таким чином, що він становить форму безпосередньої та обгрунтованої лише завдяки собі самій певності чогось, єдиним відповідним змістом якої треба вважати положення «Я є Я». I саме цей зв'язок між характерною для найвищої засади вчення про науку формою безумовної певності та єдиним відповідним їй змістом $є$ тематичним у переході від $\mathrm{X}$ до положення «Я $є$ Я».

Якщо дотримуватися цієї інтерпретації, тоді Фіхтев вибір виразу «увиразнювати» видається довільним або неспецифікованим. Він радше описує саме цей зв'язок між формою та змістом найвищої засади. Адже те, що позначена через X форма безумовної певності дістає свій відповідний зміст у положенні «Я є Я», означає, що в цьому змісті вона набуває єдиного відповідного їй викладу та єдиного доречного для неї виразу. I саме це є змістом вислову, що безумовно покладене X можна також увиразнити через положення «Я є Я». Позаяк дотепер здійснена інтерпретація зовсім не торкалася цього зв’язку, то й, здається, іiї також годі вважати реконструкцією змісту вміщеної в цьому уривку думки.

А втім, цей закид заходить у крайнощі. Поступ засвідчує, що Фіхте ймовірно говорить про стосунок умови між позначеним через $\mathrm{X}$ взаємозв'язком і положенням «Я є Я», а також згодом виснуваним з нього положенням «Я є». Отож положення «Я €» характеризується як таке, «на якому грунтується X» (SW I, S. 95; курсив мій. Ю.Ш.). Для даного переходу від Х до положення «Я є Я» 3 цього випливає, що в ньому насправді взаємно пов'язані два висловлювання. Одне висловлювання можна розуміти як висловлювання про те, що свідомість тотожності Я є умовою свідомості буття А. Інше висловлювання кваліфікує цю умову та положення «Я є» як єдиний відповідний вираз або як єдиний відповідний виклад позначеної через Х форми безпосередньої та безумовної певності.

Але цим все-таки досягнуто лише першого проміжного результату на шляху підведення до принципу вчення про науку, і сам Фіхте звертає увагу на те, що цей результат треба підпорядкувати багатьом обмеженням: по-перше, не положення «Я $є$ Я», а положення «Я є» становить мету цього шляху. Фіхте коментує, що аналіз «вже непомітно» (SW I, S. 94) підійшов до цього положення. Але доказ цьому ще треба навести. Ця теза і собі підлягає обмеженню, що положення «Я є» слід розглядати «не як вираз вчинкодіï, а все-таки як вираз факту» (ibid.). Інше обмеження випливає з дотепер зробленої реконструкції. Адже очевидно, що досі не можна було ідентифікувати аргумент, який міг би навести доказ тези, що положення «Я є Я» та «Я є» насправді є єдиним відповідним змістом позначеної через X форми безпосередньої 
певності. Природно припустити, що Фіхте вважав такий доказ зайвим, позаяк він вже даний зі свідомістю тотожності Я. Здається, це припущення підтверджує наступний п’ятий уривок, адже здійснений у ньому перехід від положення «Я є Я» до положення «Я є» відштовхується від узгодження між положенням «Я є Я» та X, a також грунтується на цьому узгодженні (SW I, S. 95). Залишається запитати про підстави для цього узгодження.

4. Положення «Я є Я» як вираз Х та перехід від положення «Я $є$ Я» до положен-

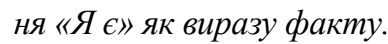

Можна розрізняти два аспекти, на підставі яких можна розуміти тезу про узгодження положення «Я $є$ Я» із Х. Перший аспект випливає 3 функції свідомості тотожності Я - бути умовою свідомості покладеного через Х буття А. Бо так само як $\mathrm{X}$, свідомість тотожності Я становить інваріантну формальну умову, яка має бути дотримана в усіх випадках, в яких застосовується X, та в яких Я має бути у змозі розуміти себе як суб'єкта свого судження. Тому свідомість тотожності Я так само, як i X, можна позначити як «закон», який, щоправда, є як X не таким законом, згідно 3 яким судить Я, а таким, що є умовою свідомості цього закону.

Але лише другий аспект виправдовує тезу Фіхте, що положення «Я є» є виразом чи викладом позначеної через X форми безумовної певності. Цей аспект стосується змісту положення «Я є Я». Цьому аспектові характерно те, що він сам по собі має стосунок до чогось наявного. Це, вочевидь, слід розглядати як зміст тези Фіхте, що положення «Я є Я» чинне безумовно й цілковито, тобто «не лише згідно із формою», а й «також згідно зі своїм змістом» (ibid.). Це єдине в даному контексті і ближче не експліковане прояснення статусу положення «Я $є$ Я» можна легко розуміти як Фіхтев варіант так званої картезіанської очевидності. Тобто якщо суб'єкт, який судить, орудує безпосереднім знанням про те, що він сам є тим, хто судить згідно з Х як із законом та усвідомлює в ньому свою тотожність щодо покладеного через X взаємозв'язку, тоді на підставі цієї своєї певності він також має безпосереднє знання про існування того, чого ця певність стосується. Позаяк це є змістом положення «Я є Я», яке увиразнює цю певність, то цей зміст можна розуміти як виклад або вираз безумовно покладеного $\mathrm{X}$, адже X позначає лише форму безумовної певності чогось.

Поступ тексту засвідчує, що таким чином слушно описувати Фіхтеве саморозуміння. Адже саме це являє собою специфічне влаштування змісту положення «Я $\epsilon$ Я», - на niдcmaвi себе мати стосунок до чогось справдi наявного чи сущого, - яке закладає підвалини ходу думок п'ятого уривку та здійсненому в ньому переходові від положення «Я є Я» і викладається Фіхте в експлікації відмінності між певністю положення «А є А» та положення «Я є Я».

Адже, - на відміну від положення «А є А», в якому існування А має лишатися проблематичним, бо інтерпретація А не є з'ясованою, - у положенні «Я є Я» мислять визначений зміст, який на підставі самого себе, а тому безумовним чином стосується чогось, що існує. А тому, як вже згадано, на відміну від положення «А $\epsilon$ А» можна сказати, що положення «Я є Я» «діє безумовно та цілковито», або що воно діє «не лише згідно з формою», а й «також згідно зі своїм змістом». I тому положення «Я є Я» можна також увиразнити через положення «Я є» (SW I, S. 94-95).

\section{5. Перехід до положення «Я є» як виразу вчинкодї}

А втім, за Фіхте, положення «Я є» спочатку треба розуміти лише як вираз факту емпіричної свідомості, тобто як положення, яке «грунтується на фактові» та не має 
«жодної іншої значущості за значущість факту» (SW I, S. 95). Відразу годі збагнути, що тут мається на увазі. Якщо притримуватися поступу тексту, тоді очевидно, що лише функиія свідомості «Я є», - бути умовою свідомості позначеного через $\mathrm{X}$ цілковито покладеного взаємозв'язку, - обгрунтовує цю тезу.

Заторкнутий перебіг аргументації в останньому абзаці п’ятого уривку спирається на той результат, що свідомість тотожності Я є умовою позначеного через X взаємозв'язку обох способів покладання А. Другий засновок, хоч він докладніше не експлікований та не обгрунтований Фіхте, полягає у тім, що умова свідомості цього безумовного взаємозв'язку зі свого боку не $є$ зумовленою, а так само має бути лише безумовно та цілковито певною ${ }^{35}$. Третій засновок повертається до того, що про цілковиту певність позначеного через X взаємозв'язку стверджували в модусі факту емпіричної свідомості. 3 цього засновку в стосунку до положення «Я є» випливає, що статус факту емпіричної свідомості відповідає не лише певності, а й також розумінню iï функції - бути «основою пояснення всіх фактів емпіричної свідомості» (SW I, S. 95).

Проте це міркування дає підгрунтя для розуміння відмінності між статусом факту й тим, що Фіхте позначив як «вчинкодію». Однак ще незрозумілим має лишатися також те, в чому полягає дефіцит, наявний, за Фіхте, тоді, коли положення «Я є» розуміють лише як вираз факту, а не як вираз вчинкодії.

Це стане зрозуміло тільки якщо зважать на таке: коли положення «Я є», як це було дотепер, тематизують лише з огляду на його функцію умови та специфічний спосіб його значущості, то це ще нічого не говорить про те, яким чином насправді постає увиразнена у ньому свідомість «Я є». Тоді Фіхтеву тезу, яка закладає підвалини останньому крокові на шляху до виявлення принципу вчення про науку, можна сформулювати так: коли Я, яке судить, й надалі розуміють як факт емпіричної свідомості, то відповідно описати зміст положення «Я є» не можна жодним чином. Це можливо лише тоді, коли залишають дотепер чинну парадигму рефлексії про факти емпіричної свідомості та переходять до нової парадигми, яку тлумачать через поняття вчинкодії. Хід аргументації шостого уривку є доказом цієї тези.

Спочатку він відхиляється від досягнутого результату та ще раз звертається до відправної точки міркування - положення «А є А». Це відбувається 3 метою позначення положення «А $є$ А» як судження. Але суть цього посилання на положення «А $€$ А» виявляється лише в наступному кроці, в якому Фіхте характеризує судження як «діяння людського духу» і таким чином уперше звертається до поняттєвої площини, на якій описується конституція змісту положення «Я є» та постання увиразненої у ньому свідомості, а також, урешті-решт, інтерпретується як «вираз вчинкодії».

Висловлювання, що будь-яке судження $є$ діянням людського духу, а воно становить перший засновок наступного ходу аргументації, треба обгрунтовувати через відсилання до «емпіричної свідомості» та «емпіричної самосвідомості», в якому «всі умови дії [...] для рефлексії слід припускати як відомі та 3'ясовані» (SW I, S. 95). На близькість цього висловлювання до Райнгольда та його критичні імплікації ми вже вказували вище. Тут слід звернути увагу на те, що відсилання до емпіричної самосвідомості зовсім не обгрунтовує істину цього висловлювання, а припускає його. Адже того, чому будь-яке судження є діянням, це висловлювання

35 Ось речення, що стосується цього: «Якщо положення $\mathrm{A}=\mathrm{A}$ (або точніше те, що в ньому цілковито покладене, тобто X) має бути певним, тоді також має бути певним положення: Я є» (SW I, S. 95) 
не пояснює зовсім, натомість пояснює лише те, щзо це треба зараховувати до фактів емпіричної свідомості.

Теза про те, що будь-яке судження є діянням, природно пояснюється тією обставиною, що судження можна розуміти як твердження про слушність чогось. Але твердження про слушність чогось не є чимось, що було б даним суб'єктові як дані відчуття і що треба лише прийняти й засвоїти, а чимось, що відсилає до виконуваної самим суб'єктом діяльності. Для Фіхте, втім, це не значить, як для Райнгольда, що саме це діяння не можна вважати предметом свідомості, як демонструє відсилання до емпіричної свідомості.

Проте ця інтерпретація не відповідає Фіхтевому саморозумінню. Позаяк Фіхте, згідно з традицією, розуміє «судження» таким чином, що воно покладає «зв'язок між різними поняттями». Оскільки при цьому припускають, «що поняття вже мають» ${ }^{36}$, то уявлення про їхній зв'язок у судженні можна пояснити через діяльність, яка не може бути даною, а яку має витворювати суб'єкт, що судить, а тому ії також можна зарахувати до змістів емпіричної самосвідомості. Тому можна сказати, що будь-яке судження «у згоді з емпіричною свідомістю є діянням людського духу».

Другий, сформульований в уривку 6-b засновок досягається в новому зверненні до позначеного через X необхідного взаємозв'язку між обома способами покладання А. У цьому засновку поєднані два часткових висловлювання. Перше часткове висловлювання («Отож підвалини цього діяння [...] закладає щось, що не засноване на чомусь вищому, тобто Х») відсилає до викладеної в п’ятому уривку тези, у згоді 3 якою X $\epsilon$ «найвищим фактом емпіричної свідомості», що, за Фіхте, «либонь, слід визнавати без жодного доказу». Те, що цю тезу слід визнавати без будь-якого доказу, можна розуміти так, що вона становить безпосередній вислід поняття Х. Позаяк тут $\mathrm{X}$ характеризує лише загальну форму певності судження, то воно, про що загадано вище, як найзагальніша, а тому найвища умова міститься в усіх судженнях, які суб'єкт свідомості стверджує як факти емпіричної свідомості.

Друге часткове висловлювання («X=Я є») також повертається до досягнутої в п’ятому уривку думки про узгодження $\mathrm{X}$ із положенням «Я є». Отож позаяк всіх фактів емпіричної свідомості стосується те, що вони увиразнюються в формі судження, що будь-яке судження $\epsilon$ діянням і що X становить найвищу умову будь-якого судження та Х узгоджується із положенням «Я є» за формою, то можна сказати, що «підвалини цього діяння [...] закладає щось, що не засноване на чомусь вищому, тобто $\mathrm{X}=$ Я $є »$.

Як і другий, так і третій здійснений в шостому уривкові крок становить скеровану поняттям діяння інтерпретацію вже здобутих результатів. Цей крок виглядає як прямий наслідок формального узгодження X та положення «Я є», а також до того стверджуваного статусу положення «Я є» - бути найвищою засадою всіх фактів емпіричної свідомості. Адже тому, що положення «Я є» узгоджується з Х з огляду на його форму, і тому, що воно є найвищою засадою емпіричної свідомості, можна сказати під керівництвом даної через поняття дії інтерпретації, що в змісті положення «Я є» міститься «цілковито покладене», а тому лише «на собі самому засноване» діяння, яке $\epsilon$ «засадою певного», тобто наявного у твердженні про цілковиту певність положення «А $є$ А» «діяння людського духу» ${ }^{37}$.

${ }_{37}^{36}$ Див. GA IV/I, S. 276. Відсиланням на це місце я завдячую Й.-П. Мітману.

${ }^{37}$ Позаяк у згоді з уривком 6-а будь-яке судження $\epsilon$ діянням, для вчення про науку постає нове завдання, на яке вказує залучене до дужок в уривку 6-с зауваження Фіхте, а саме довести, що 
Четвертий крок випливає з докладніше не експлікованої Фіхте рефлексії щодо логічної конституції поняття цілковито покладеного діяння. Позаяк цей крок витворює лише цілковито покладений, необхідний взаємозв'язок між покладеністю та буттям чогось, то й поняття цього взаємозв'язку можна назвати змістово порожнім або простим поняттям. Тому це поняття можна позначити як «чистий характер діяльності в собі, не зважаючи на його особливі емпіричні [тобто змістові - Ю.Ш.] визначення». 3 цього для Фіхте безпосередньо випливає наступний крок. Він характеризує цю чисту діяльність як таку, завдяки якій постає свідомість «Я є». Фіхте позначає ії як «покладання Я через самого себе» (SW I, S. 96). Чи справді це випливає безпосередньо?

Щоби це зрозуміти, треба відштовхуватися від того, що в положенні «Я є» міститься безумовний взаємозв'язок між змістом безпосередньої свідомості «Я» та існуванням того, хто цю свідомість має. Далі ми показали, що зміст цієї свідомості не залежить від будь-яких змістових визначень, які можна розуміти як визначення емпіричної самосвідомості. 3 цього випливає, що «Я» свідомості «Я є» не може стосуватися себе таким чином, як воно стосується чогось даного у внутрішньому досвіді та змістово відмінного від нього самого. Отож положення «Я $є$ »н $\epsilon$ фактом емпіричної свідомості. Але якщо воно не є чимось, що дане як факт емпіричної свідомості, тоді воно може бути витвореним лише первинно (auf eine ursprüngliche Weise). Але діяльність, яка його витворює, не можна описати якось інакше за те, як це досі робив Фіхте: вона спонтанна, бо не обгрунтована чимось відмінним від самого Я, і вона чиста, бо цілковито звільнена від будь-яких відмінних змістових визначень. Позаяк Я первинно витворює думку про свою власну дійсність, цю чисту та спонтанну діяльність можна позначити як «покладання Я через самого себе».

Отож позаяк Я на власній підставі витворює у цій діяльності та 3 нею думки про свою дійсність, то його, урешті-решт, можна описати як те, що є водночас «діяльним і продуктом дії; дієвим та тим, що діяльністю породжується», тож зовсім не можна розрізнити «дію та вчинок», натоміть вони є «одним і тим самим». Ця тотожність характеризує поняття вчинкодії, «а тому: $Я$, увиразнює вчинкодію» (ibid.).

Очевидно, що лише в цьому місці надолужено розвинуту у «Власних медитаціях про елементарну філософію» перспективу, у згоді з якою свідомість «Я є» постає через чисте, не пов'язане з чимось даним діяння ${ }^{38}$.

положення «Я є» становить найвищу засаду не лише діяння, що закладає підвалини положення «А є А», а й усіх способів дії людського духу.

38 Це також сенс, який закладає підвалини Фіхтевого пояснення поняття Я «як абсолютного суб'єкта». Воно таке: «Те, буття (сутність) чого полягає суто в тому, що воно покладає себе самого як суще, є Я як абсолютний суб'єкт» (SW I, S. 97). Фіхте виразно звертає увагу на змістову порожнечу свідомості «Я є» в коментарі до третього параграфу. Там сказано: «Абсолютне $Я$ першої засади не є чимось (воно не має і не може мати предиката) (SW I, S. 109). У рамках цієї статті не можна зупинитися на докладнішому аналізі та пов'язаній з ним дискусії щодо проблем, які пов'язані з Фіхтевою діє-теоретичною інтерпретацією положення «Я є». Замість цього варто звернути увагу на занедбану як в кантознавстві, так і в фіхтезнавстві проблему. Йдеться про питання зв'язку між Кантовою та Фіхтевою інтерпретацією положення «Я є». Нещодавно Р.-П. Горстман у зв’язку із Кантовою теорією Я в «паралогізмах чистого розуму» В-редакції «Критики чистого розуму» зауважив, що, на відміну від А-редакції, у ній домінує «предметно пов'язане тлумачення», яке подає Я як щось, що посутньо «слід описувати як активність, як дію», а на підставі цього він вказав на об'єктивну близькість до Фіхтевого тлумачення положення «Я є» як виразу вчинкодії [Horstmann. 1993]. Цю заувагу можна підтвердити на підставі нашого тлумачення. Якщо спочатку звернутися до Канта, то в «Паралогізмах» він тлумачить положення «Я 
Отож зрозуміло й те, чому Фіхте міг сказати в цитованих на початку самокритичних зауваженнях, що тут мається на увазі неусвідомлюваний зазвичай стан справ. Це зауваження не передбачає, що положенню «Я є» взагалі не відповідає жоден стан справ свідомості. Воно лише засвідчує, що положенню «Я є» не відповідає жоден стан справ природної, пов'язаної із предметами свідомості, а тому його можна досягнути на підставі природної свідомості, тобто пояснити як ії умову. Цю думку треба протиставляти всім спробам емпірично-психологічної інтерпретації Фіхтевого поняття Я. Отже, наприкінці виявляється, що Фіхтева спроба викладення положення «Я є» на підставі факту емпіричної свідомості як засадничий принцип його вчення про науку має не лише пропедевтичний характер, а $є$ також виразом тієї думки, що зміст положення «Я є» та його характер, що увиразнює не подибувану в природній свідомості «вчинкодію», можна все-таки прояснити на підставі природної свідомості.

\section{СПИСОК ЛITЕРАТУРИ / REFERENCES}

Baumanns (1974): Baumanns P. Fichtes Wissenschaftslehre: Probleme ihres Anfangs; mit einem Kommentar zu [section symbol] 1 der Grundlage der gesamten Wissenschaftslehre. Bonn: Bouvier Verlag H. Grundmann, 1974, 238 S.

Baumgartner, Jacobs (1968): Baumgartner, H.M. \& Jacobs, W.G. J.G. Fichte-Bibliographie. Stuttgart-Bad Cannstatt: F. Frommann, 1968, 346 S.

Fichte (1845): Johann Gottlieb Fichte's sämmtliche Werke, in 8 Bänden. Hrsg. v. Immanuel Hermann Fichte. Berlin: Veit und Comp., 1845-1846. (у посиланнях: SW із зазначенням тому та сторінки)

Fichte (1962f): Fichte, J.G. Gesamtausgabe der Bayerischen Akademie der Wissenschaften. Hrsg. v. R. Lauth und H. Jacob. Stuttgart-Bad Cannstatt: Frommann-Holzboog, 1962f. (у посиланнях: GA із зазначенням серії, тому та сторінки)

Girndt (1984): Girndt, H. «Forschungen zu Fichte seit Beginn und im Umkreis der kritischen Edition seiner Werke 1962». In: Zeitschrift für philosophische Forschungen. Bd. 38, Heft 1, 1984, S. 100-110.

Henrich (1966): Henrich, D. «Fichtes ursprüngliche Einsicht». In: Subjektivität und Metaphysik. Festschrift für Wolfgang Cramer. Hrsg. von D. Henrich u. H. Wagner. Frankfurt a. M. 1966, S. $188-232$.

\footnotetext{
мислю» як «невизначене емпіричне споглядання, тобто сприйняття», до якого можна застосувати існування, але не в сенсі категорії. Теза про «невизначене сприйняття» має на увазі, - що Кант намагається уточнити без поняттєвих зусиль, - не «емпіричне уявлення», а таке, що є «чисто інтелектуальним», «бо воно належить до мислення взагалі». А втім, вона означає «щось реальне, що дане, а саме [...] як щось, що існує насправді, а в положенні “я мислю” позначене як таке», яке Кант потім розуміє як тотожне з положенням «Я є» (Див. В 422). Кант міркує далі, що «без емпіричного уявлення, яке дає матерію для мислення, [...] акт “Я мислю” все-таки не мав би місця» (В 423/4). Доказами близькості до Фіхтевого поняття вчинкодії може слугувати останній крок $\S 1$ на шляху до тлумачення положення «Я є» як виразу вчинкодії. Адже для цього кроку також передбачається стосунок до акту мислення, який репрезентовано в судженні «А є А», яке Фіхте позначає як діяння. Ця дія, за Кантом, є «матерією для мислення», без якої висловлена в положенні «Я є» свідомість була би неможливою. Вона завдячує своїм існуванням як таким безумовній дії, яку Фіхте характеризує як вчинкодію. Те, що увиразнену в положенні «Я мислю» самосвідомість Кант розуміє як цілковито просте та «чисто інтелектуальне» уявлення, яке, втім, стосується чогось реального, що як таке не дане, натомість породжене «актом спонтанності» (В 132), а тому тотожне положенню «Я є», ще не прояснює об’ єктивної близькості між цією концепцією та Фіхтевим поняттям інтелектуального споглядання та вчинкодії. Такій близькості слід присвятити окреме дослідження.
} 
Henrich (1970): Henrich, D. «Selbstbewußtsein. Kritische Einleitung in eine Theorie». In: Hermeneutik und Dialektik. Festschrift für Hans-Georg Gadamer. Hrsg. v. R. Bubner, K. Cramer, R. Wiehl. Bd. I. Tübingen: Mohr, 1970, S. 257-284.

Henrich (1976): Henrich, D. Identität und Objektivität. Eine Untersuchung über Kants transzendentale Deduktion. Heidelberg: Winter, 1976, $112 \mathrm{~S}$.

Henrich (1989): Henrich, D. «Die Anfänge der Theorie des Subjekts (1789)». In: Zwischenbetrachtung. Im Prozeß der Aufklärung. Jürgen Habermas zum 60. Geburtstag. Frankfurt a. M.: Suhrkamp, 1989, S. 106-170.

Henrich (1991): Henrich, D. «Die Erschließung eines Denkraums. Bericht über ein Forschungsprogramm zur Entstehung der klassischen deutschen Philosophie nach Kant in Jena 17891795». In: Henrich, D. Konstellationen. Probleme und Debatten am Ursprung der idealistischer Philosophie (1789-1795). Stuttgart: : Klett-Cotta, 1991, S. 215-263.

Horstmann (1987): Horstmann, R.-P. «Gibt es ein philosophisches Problem des Selbstbewußtseins?» In: Theorie der Subjektivität. Hrsg. v. K. Cramer, H. F. Fulda, R.-P. Horstmann, U. Pothast. Frankfurt a. M., 1987, S. 220-248.

Horstmann (1993): Horstmann R.-P. «Kants Paralogismen». In: Kant-Studien, Bd. 84, 1993, Heft 4, S. 408-425.

J. G. Fichte-Bibliographie... (1993): J. G. Fichte-Bibliographie (1968-1992/3). Hrsg. v. S. Doyé. Fichte-Studien-Supplementa, B. 3. Amsterdam: Rodopi, 1993, (vii) $383 \mathrm{~S}$.

Kant $(1998)=$ B: Kant, I. Kritik der reinen Vernunft. Hrsg. v. Jens Timmermann. Hamburg: Meiner, 1998, (xxiv) $995 \mathrm{~S}$.

Mittmann (1993): Mittmann, J.-P. Das Prinzip der Selbstgewissheit. Fichte und die Entwicklung der nachkantischen Grundsatzphilosophie. Athenaums Monografien, Philosophie, Bd. 270. Bodenheim: Athenaum, 1993, (iv) $210 \mathrm{~S}$.

Niethammer (1795a): Niethammer, F.I. «Von den Ansprüchen des gemeinen Verstandes an die Philosophie». In: Philosophische Journal einer Gesellschaft Teutscher Gelehrten. Hrsg. v. Friedrich Immanuel Niethammer, Erster Band. Neu-Strelitz, 1795, S. 3-45.

Niethammer (1795b): Niethammer, F.I. «Vorbericht über Zweck und Einrichtung diese Journals». In: Philosophisches Journal..., 1795, без нумерації сторінок.

Pothast (1971): Pothast, U. Über einige Fragen der Selbstbeziehung. Frankfurt a. M. 1971, 48.

Reinhold (1789): Reinhold, K. L. Versuch einer neuen Theorie des menschlichen Vorstellungsvermögens. Prag/Jena, 1789 (2. Aufl. 1795); Nachdruck der 1. Aufl. Darmstadt: Wissenschaftliche Buchgesellschaft, 1963, 579 S.

Reinhold (1794): Reinhold, K.L. «Ueber den Unterschied zwischen dem gesunden Verstande und der philosophierenden Vernunft in Rücksicht auf die Fundamente des durch beyde möglichen Wissens». In: Beyträge zur Berichtigung bisheriger Mißverständnisse der Philosophen. Zweyter Band die Fundamente des philosophischen Wissens, der Metaphysik, Moral, moralischen Religion und Geschmackslehre betreffend. Jena: Mauke, 1794, S. 3-72.

Selbstbewußtseinstheorien... (1991): Selbstbewußtseinstheorien von Fichte bis Sartre. Hrsg. u. mit einem Nachwort versehen v. Manfred Frank. Frankfurt a. M.: Suhrkamp, 1991, 599 S.

Stamm \& Bernecker (1994): Stamm, M. \& Bernecker, S. Elementarphilosophie. Gründe und Folgen der Systemkrise Karl Leonhard Reinholds (1790-1792). Einleitung v. D. Henrich. Stuttgart: Klett-Cotta, 1993, $650 \mathrm{~S}$.

Stolzenberg (1986): Stolzenberg, J. Fichtes Begriff der intellektuellen Anschauung. Seine Entwicklung in den Wissenschaftslehren von 1793/94 bis 1801/02. Stuttgart: Klett-Cotta, 1986, (xii) $413 \mathrm{~S}$.

Stolzenberg (1990): Stolzenberg, J. «El "YO" de Fichte. En torno al parágrafo 1 de la "Grundlage der gesamten Wissenschaftslehre" de 1794». In: Pensamiento critico, Etica y Absoluto, Homenaje a José Manzana 1928-1978. Ed. V.J.M. Aguirre, X. Insausti. Victoriensia, Publicaciones del Seminario de Victoria, Vol. 58. Vitoria, Editorial ESET, 1990, pp. 203232.

Tugendhat (1979): Tugendhat, E. Selbstbewußtsein und Selbstbestimmung: sprachanalytische Untersuchungen. Frankfurt a. M.: Suhrkamp, 1979, 364 S. 
Weißhuhn (1794): Weißhuhn, F.A. «Rezension auf Fichtes "Über den Begriff der Wissenschaftslehre oder sogenannten Philosophie"». In: Philosophisches Journal für Moralität, Religion und Menschenwohl. Hrsg. v. Carl Christian Erhard Schmid. Bd. 4, St. 1. Jena, 1794, S. 139158.

Weißhuhn (1795): Weißhuhn, F.A. «Sätze und Gegensätze zur Grundlegung eines neuen Systems der Philosophie». In: Philosophisches Journal einer Gesellschaft Teutscher Gelehrten. Hrsg. v. Friedrich Immanuel Niethammer. Bd. 2, Heft 6. Neu-Strelitz, 1795, S. 85-115.

Wolff (1983): Wolff, Ch. Gesammelte Werke; II. Abteilung.: Lateinische Schriften. Band 1.2: Philosophia Rationalis sive Logica, Pars II. Hrsg. u. bearb. v. J. Ecole. Hildesheim, Zürich, New York: G. Olms, 1983, (ccxxxiii) 537 S.

Стаття одержана редакцією / Received 28.08.2014

\section{Jürgen Stolzenberg}

\section{Fichte's Proposition «I am»}

The paper deals with Johann Gottlieb Fichte's argument in $\S 1$ of the «Foundations of the Science of Knowledge» (1794). Reconstructing the crucial argument of the $\S 1$ of «Foundations...» step by step, the author shows how Fichte infers the proposition «I am» from the logical proposition of identity «A is A». In doing so, the author claims that proposition «I am», which expresses what Fichte calls «Tathandlung», has to be understood as a critical response to Carl Leonhard Reinhold's methodological program which emphasizes the starting point of philosophy as a «fact of consciousness». Furthermore, the paper shows the difference between Fichte's argument of the $\S 1$ of «Foundations...» and his first attempt of its application in the «Private Meditations on Elementary Philosophy» (1793/94) which deals with the concept of an intellectual intuition of the «I» and which in turn can be understood as referring to a fact of consciousness. Therefore, Fichte's argument leading to the proposition «I am» in the $\S 1$ of «Foundations...», is the result of a self-critical revision of his very first conception of the «I»).

Jürgen Stolzenberg, Professor Emeritus, Martin-Luther-Universität Halle-Wittenberg,

Юрген Штольценберг, професор-емерит університету Мартина Лютера Гале-Вітенберт (Гале, Німеччина)

Юрген Штольценберг, профессор-эмерит университета Мартина Лютера ГаллеВиттенберг (Галле, Германия)

e-mail: stolzenberg@phil.uni-halle.de 